\title{
The Development of Approaches to Learning and Perceptions of the Teaching-Learning Environment During Bachelor Level Studies and Their Relation to Study Success
}

\author{
Henna Asikainen ${ }^{1}$, Anna Parpala ${ }^{2}$, Sari Lindblom-Ylänne ${ }^{2}$, Gert Vanthournout ${ }^{3,4} \&$ Liesje Coertjens $^{5}$ \\ ${ }^{1}$ University of Helsinki, Faculty of Biological and Environmental Sciences, University of Helsinki, Finland \\ ${ }^{2}$ University of Helsinki, Faculty of Behavioural Sciences, University of Helsinki, Finland \\ ${ }^{3}$ University of Antwerpen, Institute of Education and Information Sciences, Stadscampus, Belgium \\ ${ }^{4}$ Interdisciplinary Department for Teacher Education, Vrije Universiteit Brussel, Belgium \\ ${ }^{5}$ University of Antwerpen, Institute of Education and Information Sciences, Stadscampus, Antwerpen, Belgium \\ Correspondence: David Wolf II, School of Management, Northern Canada University, Toronto, ON., M3A 2K7, \\ Canada. Tel: 1-613-947-3592. E-mail: davidwolf@gc.ca
}

Received: June 24, 2014 Accepted: July 22, 2014 Online Published: July 30, 2014

doi:10.5539/hes.v4n4p24 URL: http://dx.doi.org/hes.v4n4p24

\begin{abstract}
The aim of the present study is to explore changes both in approaches to learning as well as in students' experiences of the teaching-learning environment and how these changes are related to each other during their Bachelor studies by using a longitudinal data set. The aim is further to explore how students' approaches to learning and their perceptions of the teaching-learning environment relate to study success. Participants comprised of 103 students at the Faculty of Biological and Environmental Sciences who participated in the present study from the first to third year of their Bachelor degree studies. We used a modified version of the ETLQ questionnaire and conducted Confirmatory factor analyses on scales representing approaches to learning and the teaching-learning environment at both measurements. We investigated changes at the group level using a paired sample t-test and conducted the final analysis with regression analyses. We then used Structural Equation Modelling to analyse the relationship between approaches to learning, perceptions of the teaching-learning environment, and study success. The results showed an increase in the deep approach to learning and a decrease in students' perceptions of teaching for understanding. Organised studying and interest in studies were related to study success. The results reveal the existence of complex relations between changes in approaches to learning and perceptions of the teaching-learning environment.
\end{abstract}

Keywords: peer assessment, bioscience, higher education

\section{Introduction}

Universities face growing challenges in educating students as life-long learners and experts in their own fields. To attain these goals, higher education should promote deep-level learning and understanding as well as versatile expertise in students (Biggs, 1999; Dochy, Segers, \& Buehl, 1999). To this end, students are expected to develop their understanding of the subject matter and critical thinking during their university studies. One way of determining whether students succeed in this development is to see how students' approaches to learning develop during their studies, because the deep approach to learning measures how students go about learning in their studying.

The decades since the 1970's have seen several studies of university students' learning (Entwistle, McCune, \& Hounsell, 2003; Entwistle \& Ramsden, 1983; Marton, Hounsell, \& Entwistle, 1984; Marton \& Säljö, 1976; Parpala, Lindblom-Ylänne, Komulainen, Litmanen, \& Hirsto, 2010). In among the early studies, Marton and Säljö (1976) distinguished two qualitatively different ways in which students processed information: surface and deep. Students who used deep processing sought to understand the meaning of the article for themselves, whereas students who use surface processing in their learning aimed to memorise details about the article in order to answer questions about it afterwards. Since then, studies refer to these qualitatively different ways of studying as the deep and surface approaches to learning, which describe students' intentions and study processes 
(Marton \& Säljö, 1984). Because assessment and awareness of assessment criteria guide student learning, an additional approach was introduced, namely, a strategic approach (Entwistle \& Ramsden, 1983) or an achieving approach (Biggs, 1987). This approach refers to how ambitious and organised students are. Currently, research on approaches to learning refers mainly to organised studying or organised effort in studying, which emphasises good time management, self-regulation and effort in studying (Entwistle \& McCune, 2004). Studies have suggested that the combination of the deep approach to learning and organised studying are related to better learning outcomes (Entwistle \& Ramsden, 1983; Lindblom-Ylänne, 1999).

Students' perceptions of the teaching-learning environment are related to their approaches to learning. Entwistle, McCune and Hounsell (2003) introduced the concept teaching-learning environment to describe different aspects of the academic environment that are potential in supporting student quality learning including aspects of course design and organisation, teaching and assessing, staff-student relationship and peer support. Previous studies have shown that students' perceptions of the teaching-learning environment are positively related to the deep approach to learning and negatively related to the surface approach to learning (Entwistle \& Tait, 1995; Richardson, 2005; Richardson, 2006). That is to say, students who apply a deep approach to learning in their studying tend to experience all the factors of the teaching-learning environment more positively than students who apply a surface approach to learning. For example, positive perceptions of teaching are positively related to the deep approach to learning and negative related to the surface approach to learning (Diseth, 2007a; Diseth, 2007b; Prosser \& Trigwell, 1999). According to Biggs (2003), teaching should be based on constructive alignment, meaning that the learning objectives, teaching methods and assessment should be in line with each other. Teaching, which is properly aligned, is more likely to promote the deep approach to learning and qualitatively better learning outcomes (Biggs, 1999). Also, research has found that students' perceptions of alignment in teaching are related to the deep approach to learning (Parpala et al., 2010). In addition, the support students give to each other have been found important in studies (Rytkönen, Parpala, Lindblom-Ylänne, Virtanen, \& Postareff, 2012). Students' perceptions of peer support have been found to be positively related to the deep approach and negatively related to the surface approach (Entwistle et al., 2003; Parpala, Lindblom-Ylänne, Komulainen, \& Entwistle, 2013).

Although a development in students' critical thinking and understanding would be expected during studies, results concerning the development of students' approaches to learning during their studies are not unambiguous. According to earlier studies, students' deep approach to learning does not change over time (Lietz \& Matthews, 2010; Zeegers, 2004). In addition, a few studies have found a decline in the deep approach after a three-year period of studying (Biggs, 1987; Watkins \& Hattie, 1985; Wilding \& Andrews, 2006). According to Richardson (2011), the stability of students' approaches to learning over time could also indicate similarities in their learning environments during their studies. An earlier study found no changes in science students' perceptions of their learning environment during Bachelor studies from the first year to their third year (Rytkönen \& Parpala, 2010). Despite the strong relationship between students' perceptions of the teaching-learning environment and approaches to learning, previous studies have not explored the relationship between the change in students' perceptions of the teaching-learning environment and the change in approaches to learning during Bachelor studies. At the course level, research has shown that changes in students' perceptions of assessment were unrelated to changes in the deep approach to learning, and that the initial deep approach seems to explain the deep approach at the end of the course more strongly than the students' perceptions of assessment (Gijbels, Segers, \& Struyf, 2008). Exploring the relationship between the development in students' experiences of the teaching-learning environment and approaches to learning is important to see what kind of changes in the teaching-learning environment could support the development of learning and studying which is desired.

Several studies have explored the relationship between approaches to learning and academic achievement (Entwistle \& Ramsden, 1983; Lizzio, Wilson, \& Simons, 2002; Richardson, 2006) but the studies have had contradictory results. Some studies have indicated that the deep approach to learning is positively (Román, Cuestas, \& Fenollar, 2008), and surface approach is negatively related to academic achievement (Diseth, 2003; Diseth \& Martinsen, 2003). Other studies have also found a positive relationship between the strategic approach and academic achievement (Diseth, 2007a; Diseth, 2007b; Entwistle \& Ramsden, 1983). However, among science students a positive relationship between the surface approach and study success has been found (Lizzio et al., 2002). According to our earlier study, organised studying and students' perceptions of peer support in studies are related to study success among first-year students in the Faculty of Biological and Environmental Sciences (Rytkönen et al., 2012). But we found no relation between deep approaches to learning and study success. A follow-up would bring important information about the relationship between learning and studying and study success in the final year of Bachelor studies. It would be more likely to find a positive relation 
between study success and the deep approach because the courses are supposed to require more understanding and relating ideas from students than introductory courses in the first-year studies.

The aim of this study is three-fold. First, the aim is to explore how students' deep approach and organised studying and their perceptions of the teaching-learning environment develop during Bachelor studies in the Faculty of Biological and Environmental Sciences. Second, the aim of the present study is to analyse how changes in approaches to learning and perceptions of their teaching-learning environment are related to each other. Third, the purpose is to explore how students' approaches to learning and their perceptions of the teaching-learning environment are related to academic achievement during Bachelor studies.

We would expect the deep approach to develop during Bachelor studies because in the third-year studies students are expected to have developed in their understanding of the subject matter and critical thinking during their studies. In addition, we would expect the organised studying to increase during studies due to the changed nature of the teaching-learning environment that require more planning and effort from students. We also expect both deep approach and organised studying to be related to study success. We would expect students' perceptions of the teaching-learning environment to be more positive in their final year of studies because of teaching is more focused on specific subjects and application of knowledge. In addition, we would expect students' perceptions of the teaching-learning environment to increase together with their deep approach to learning.

\section{Method}

\subsection{Context and Participants}

The Faculty of Biological and Environmental Sciences comprise six different Bachelor programs. The largest of them is the Bachelor program of biology which comprises seven different major subjects. The other Bachelor programs comprise biochemistry, limnology and fishery science, environmental protection, biotechnology and environmental ecology. During the first year of studies in the Faculty of Biological and Environmental Sciences, the purpose is to initiate students into different areas of biology, and the curriculum is quite school like: the studies are pre-scheduled for the students and all first year students take the same courses. The third year of studies is quite different, as it no longer uses pre-set schedules; optional courses are emphasised more than compulsory courses. Students can choose courses from a wide range of optional courses. Biology students, for example, can choose their learning paths from 19 possibilities. Also, courses in the third year of study concentrate more on applying knowledge, whereas the studies in the first year consist of foundation courses which introduce different subject areas.

Two cohorts of first-year students $(\mathrm{N}=188)$ who started their studies in the fall 2007 and 2008 answered an online questionnaire on a voluntary basis in the spring of $2008(\mathrm{~N}=93)$ and $2009(\mathrm{~N}=95)$. Altogether 103 of these students participated in the follow-up study in the spring of $2010(\mathrm{~N}=50)$ and $2011(\mathrm{~N}=53)$ in the end of their third year of studying. The two cohorts were compared according to their approaches to learning, perceptions of their teaching-learning environment and study success as well as background variables. No statistically significant differences were found between these two groups. The response rate in the first year was $74.3 \%$, and $54.8 \%$ of these students participated in the follow-up study. Their ages ranged from 18 to $55(\mathrm{M}=21.54, \mathrm{SD}=4.8)$, although, $80 \%$ of the participants were under the age of 23 . The participants comprised 30 male and 78 female students. In 2008, the percentage of male students in the Faculty of Biological and Environmental Sciences was $32 \%$. Thus, the male students (38\%) were slightly overrepresented in the present data.

\subsection{Research Instrument}

The data were collected with an online questionnaire. The questionnaire used in this study was the Experiences of Teaching and Learning Questionnaire (ETLQ) constructed by Entwistle, McCune and Hounsell (2003) and modified for the Finnish context (Parpala, 2010). The ETLQ was developed to measure how specific changes in the teaching-learning environment affect students' approaches to studying (Entwistle \& McCune, 2004). The original ETLQ focuses on experiences in a course unit or module, whereas the version used in the present study focused on studying in the students' major subject more generally. The questionnaire contained 40 items measuring students' positive perceptions of their teaching-learning environment and 21 items measuring students' approaches to learning. The present study used a shortened version of the questionnaire (Rytkönen et al., 2012), which comprised 21 items about students' positive perceptions of their teaching-learning environment and 11 items about students' approaches to learning. Lastly, we measured study success with students' grade point averages (GPA) for the whole academic year.

\subsection{Analyses}


First, we conducted confirmatory factor analyses on scales that measure approaches to learning and perceptions of the teaching-learning environment. Second, the change in students' approaches to learning and perceptions of the teaching-learning environment at the group level was explored with paired sample t-tests. The relationship between changes in students' approaches to learning and their perceptions of the teaching-learning environment were similarly explored in a study conducted by Gijbels et al. (2008). First, we analysed the relationship between the changes using Pearson correlation with change variables by subtracting the students' first measurement scores from their second measurement scores. The change variables served to explore the directions of the relationships between changes, we used stepwise regression analysis to conduct the final analyses by exploring how much variance in the students' deep approach and organised studying could be attributed to the initial approach to learning and how much variance is attributable to changes in students' perceptions of their teaching-learning environment. The relationship between their approaches to learning, their perceptions of the teaching-learning environment and study success was analysed with Pearson's correlation and structural equation modelling with Amos 18.

\section{Results}

First, we report the results of the confirmatory factor analyses of the students' approaches to learning and their perceptions of the teaching-learning environment. Second, we report the results concerning the change in the students' approaches to learning and their perceptions of the teaching-learning environment as well as how they are connected to each other. Third, we explore the relationship between approaches to learning, perceptions of the teaching-learning environment and study success.

First we conducted a missing value analysis (EM). Two cases were deleted from the analysis because there were too many missing items. Seven values were missing from the item Talking with other students helped me to develop my understanding; otherwise, missing values were few (0-3.8\%). Second, we compared the student group which participated in both measurements of the study to the students who participated only in the first measurement. We found no differences between these students according to their approaches to learning, perceptions of the teaching-learning environment, and study success in the first-year data. The comparison between those student who began their studies in 2007 and 2008 revealed no differences between these two groups; the analysis is reported in greater detail in our previous study (Rytkönen et al., 2012).

Confirmatory factor analyses were first conducted on scales representing students' approaches to learning. In both measurements a model with two scales, organised studying and the deep approach which included items that measure deep-level processing, fit the model best. In the first measurement the model fit was very good $\left(\chi^{2}=16.64, \mathrm{df}=13\right.$, RMSEA $\left.=0.052, \mathrm{CFI}=0.972\right)$. In the second measurement, an error covariate was added between two items that measure organised studying, thus making it acceptable $\left(\chi^{2}=20.30 \mathrm{df}=12\right.$, RMSEA $=0.081$, $\mathrm{CFI}=0.920$ ). RMSEA describes how well the model would fit the covariance matrix of the population. Usually values up to .08 can be regarded acceptable, but it has been argued that values up to 0.10 can be justifiable (Hair, Black, Babin, Anderson, \& Tatham, 2006). Studies have suggested that the combination of the deep approach and organised studying is related to better learning outcomes (Asikainen, Parpala, Virtanen, \& Lindblom-Ylänne, 2013a; Entwistle \& Ramsden, 1983), and thus, these components can be regarded as desirable in university studies. Exploring the development in students' deep-level processes as well as organising and effort management during studies bring us information about the components of learning and studying which are expected to develop. Furthermore, the model fit with regard to students' perceptions of the teaching-learning environment was the best for four scales: teaching for understanding, peer support, alignment and interest and relevance. The first measurement fit the model fairly well with the covariance between two items measuring Alignment $\left(\chi^{2}=102.41 \mathrm{df}=70, \mathrm{RMSEA}=0.066, \mathrm{CFI}=0.927\right)$. The four scales describing students' perceptions of the teaching-learning environment in the second measurement also fit the model well $\left(\chi^{2}=97.42 \mathrm{df}=70\right.$, RMSEA $=0.061, \mathrm{CFI}=0.946)$. The scales can be seen in Table 1 . 
Table 1. The scales measuring approaches to learning and perceptions of the teaching-learning environment

\begin{tabular}{ll}
\hline \multicolumn{1}{c}{ Scales } & \multicolumn{1}{c}{ Items } \\
\hline Deep approach & I've looked at evidence carefully to reach my own conclusion about what I'm \\
studying & Ideas I've come across in my academic reading often set me off on long chains of \\
thought & When I've been communicating ideas, I've thought over how well I've got my \\
points across & If I've not understood things well enough when studying, I've tried a different \\
approach & On the whole, I've been quite systematic and organised in my studying \\
I have generally put a lot of effort into my studying \\
I've organised my study time carefully to make the best use of it \\
\hline Organised studying & The teaching has given me a sense of what goes on 'behind the scenes' in this \\
understanding & subject area \\
& The teaching helps me to think about the evidence underpinning different views \\
& Teaching encouraged me to relate what I learned to issues in the wider world \\
Staff helped us to see how you are supposed to think and reach conclusions in this \\
subject
\end{tabular}

\subsection{Changes in Students' Approaches to Learning and Perceptions of The Teaching-Learning Environment}

The results of the Paired sample t-test analyses showed a statistically significant increase in the deep approach $(t=-2.96, d f=105, p=0.004$, Cohen's $d=-0.313)$ from the first year to the final year of Bachelor studies. We found no statistically significant changes in organised studying. Furthermore, all the scales describing the students' perceptions of the teaching-learning environment decreased during Bachelor studies, but only the decrease on teaching for understanding scale $(\mathrm{t}=2.43, \mathrm{p}=0.017)$ was significantly lower in the third year than in the first year. The results of the Paired sample t-test appear in Table 2. 
Table 2. The change in approaches to learning and the teaching-learning environment by the paired sample

\begin{tabular}{llllll}
\hline & mean 1 & mean2 & SD & t & p \\
\hline Organised & 3.28 & 3.21 & 0.77 & 0.83 & 0.410 \\
Deep & $\mathbf{3 . 0 0}$ & $\mathbf{3 . 2 2}$ & $\mathbf{0 . 7 4}$ & $\mathbf{- 2 . 9 6}$ & $\mathbf{0 . 0 0 4}$ \\
TFU & $\mathbf{3 . 7 5}$ & $\mathbf{3 . 6 2}$ & $\mathbf{0 . 7 6}$ & $\mathbf{2 . 4 3}$ & $\mathbf{0 . 0 1 7}$ \\
Alignment & 3.62 & 3.57 & 0.64 & 0.79 & 0.429 \\
Interest \& relevance & 3.88 & 3.77 & 0.90 & 1.23 & 0.222 \\
Peer support & 4.14 & 4.23 & 0.76 & -1.21 & 0.228 \\
\hline
\end{tabular}

Next, we used Pearson correlation with change variables to explore the relationship between the changes in students' approaches to learning and perceptions of the teaching-learning environment. The change in the Deep approach correlated positively with the change in Teaching for understanding. The change in organised studying correlated statistically significantly with interest and relevance. No other changes in the students' perceptions of the teaching-learning environment were related to changes in their approaches to learning. The correlations of the change variables appear in Table 3.

Table 3. Correlations between the change variables of approaches to learning and perceptions of the teaching-learning environment

\begin{tabular}{llllllllll}
\hline Change variables & & \multicolumn{1}{c}{ Correlations } \\
\hline & Mean & SD & 1 & 2 & 3 & 4 & 5 & 6 \\
1 Relevance and evoking interest & -0.10 & 0.9 & 1 & & & & & \\
2 Peer support & 0.09 & 0.76 & $\mathbf{0 . 4 0 * *}$ & 1 & & & & \\
& & & & & & & & \\
3 Alignment & -0.05 & 0.63 & $\mathbf{0 . 4 9 * *}$ & $\mathbf{0 . 3 2 * *}$ & 1 & & & \\
4 TFU & -0.17 & 0.76 & $\mathbf{0 . 6 0} * *$ & $\mathbf{0 . 4 3} * *$ & $\mathbf{0 . 3 8 * *}$ & 1 & & \\
5 Organised studying & -0.06 & 0.74 & $\mathbf{0 . 2 0 *}$ & 0.12 & 0.07 & 0.13 & 1 & \\
6 Deep approach & 0.22 & 0.77 & 0.11 & -0.01 & 0.03 & $\mathbf{0 . 3 2} * *$ & 0.03 & 1 \\
\hline
\end{tabular}

$* \mathrm{p}<0.05,{ }^{* *} \mathrm{p}<0.01$ statistically significant correlations appear in bold

To better understand the relationship between changes in the students' approaches to learning and their perceptions of the teaching-learning environment, we conducted stepwise regression analyses on the basis of the correlational analyses of the change variables. The purpose was to analyse how much variance in the changes in the students' approaches to learning can be attributed to the score on their approaches to learning in the first year and to the changes in their perception of their teaching-learning environment. According to the analyses, $16 \%$ of the variance of the deep approach is attributable to the deep approach at the beginning of their studies. The change in their perceptions of teaching for understanding also influenced changes in the deep approach: changes in teaching for understanding and deep approach together explain 35\% of the variance. Organised studying in the first measurement explained $26 \%$ of the variance in organised studying in the second measurement, and was significantly lower in the third year than in the first year $(t=2.43, d f=105, p=0.017$, Cohen's $d=0.279)$. The students' perceptions of their teaching-learning environment were not significant predictors of organised studying. The analyses appear in Table 4. 
Table 4. Stepwise regression analyses

\begin{tabular}{|c|c|c|c|}
\hline Change in approaches to learning & Beta & $\mathbf{t}$ & $\mathbf{p}$ \\
\hline \multicolumn{4}{|l|}{ Predicting deep approach in the second measurement } \\
\hline Deep approach first measurement & 0.40 & 4.45 & $<0.001$ \\
\hline Deep approach + Teaching for understanding & 0.45 & 5.34 & $<0.001$ \\
\hline \multicolumn{4}{|l|}{$\mathrm{R}=0.594$, Adjusted $\mathrm{R}^{2}=0.333, \mathrm{~F}=18.50, \mathrm{p}<0.001$} \\
\hline \multicolumn{4}{|l|}{ Predicting organised studying in the second measurement } \\
\hline Organised studying first measurement & 0.53 & 6.10 & $<0.001$ \\
\hline $\mathrm{R}=0.513, \mathrm{R}^{2}=0.263, \mathrm{~F}=37.11, \mathrm{p}<0.001$ & & & \\
\hline
\end{tabular}

\subsection{The Relationship Between Perceptions of the Teaching-Learning Environment, Approaches to Learning and Study Success.}

First, we explored correlations among deep approach, organised studying, perceptions of the teaching-learning environment and study success in the final year. All factors describing students' perceptions of the teaching-learning environment correlated significantly positively with each other $(p<0.05)$. In addition, the deep approach correlated positively with organised studying $(\mathrm{p}=0.04)$. Furthermore, study success correlated positively with interest and relevance and organised studying. The correlations can be seen in Table 5 .

Table 5. The correlations between perceptions of the teaching-learning environment, approaches to learning and study success in the final year.

\begin{tabular}{|c|c|c|c|c|c|c|c|}
\hline \multirow[t]{2}{*}{ Scales } & \multicolumn{7}{|c|}{ Correlations } \\
\hline & 1 & 2 & 3 & 4 & 5 & 6 & 7 \\
\hline 1Relevance and evoking interest & 1 & & & & & & \\
\hline 2 Peer support & $0.25 * *$ & 1 & & & & & \\
\hline 3 Alignment & $0.56 * *$ & $0.30 * *$ & 1 & & & & \\
\hline $4 \mathrm{TFU}$ & $0.50 * *$ & $0.20 *$ & $0.60 * *$ & 1 & & & \\
\hline 5 Organised studying & 0.18 & -0.04 & $0.22 *$ & 0.11 & 1 & & \\
\hline 6 Deep approach & $0.31 * *$ & 0.18 & $0.30 * *$ & $0.48 * *$ & $0.20 *$ & 1 & \\
\hline 7 Study success & $0.24 *$ & 0.08 & 0.10 & 0.12 & $0.22 *$ & 0.18 & 1 \\
\hline
\end{tabular}

$* \mathrm{p}<0.05, * * \mathrm{p}<0.01$ statistically significant correlations appear in bold

We conducted the SEM model using factors that predict study success in their final year of Bachelor degree studies from both first and final year measurements. First we tested a model with all the scales measuring the deep approach, organised studying, experiences of the teaching-learning environment from both measurements and study success from the final year. The chi square test did not reject the model, but the number of the parameters was too big in the model in relation to the sample size. The scales measuring students' experiences of the teaching-learning environment had very little effect on study success except of the Interest and Relevance scale. Thus, Peer support, Alignment and Teaching for understanding were excluded from the analysis. The final model fit the data well $\left(\chi^{2}=11.06, \mathrm{df}=9, \mathrm{p}=0.27, \mathrm{RMSEA}=0.047, \mathrm{CFI}=0.972, \mathrm{RMR}=0.036\right)$. According to the model the deep approach in the first year positively predicted study success in the final year of Bachelor studies, whereas the effect of the deep approach in the final year was very low. Organised studying in the final year predicted study success, as did students' perceptions of interest and Relevance. The model appears in Figure 1. 


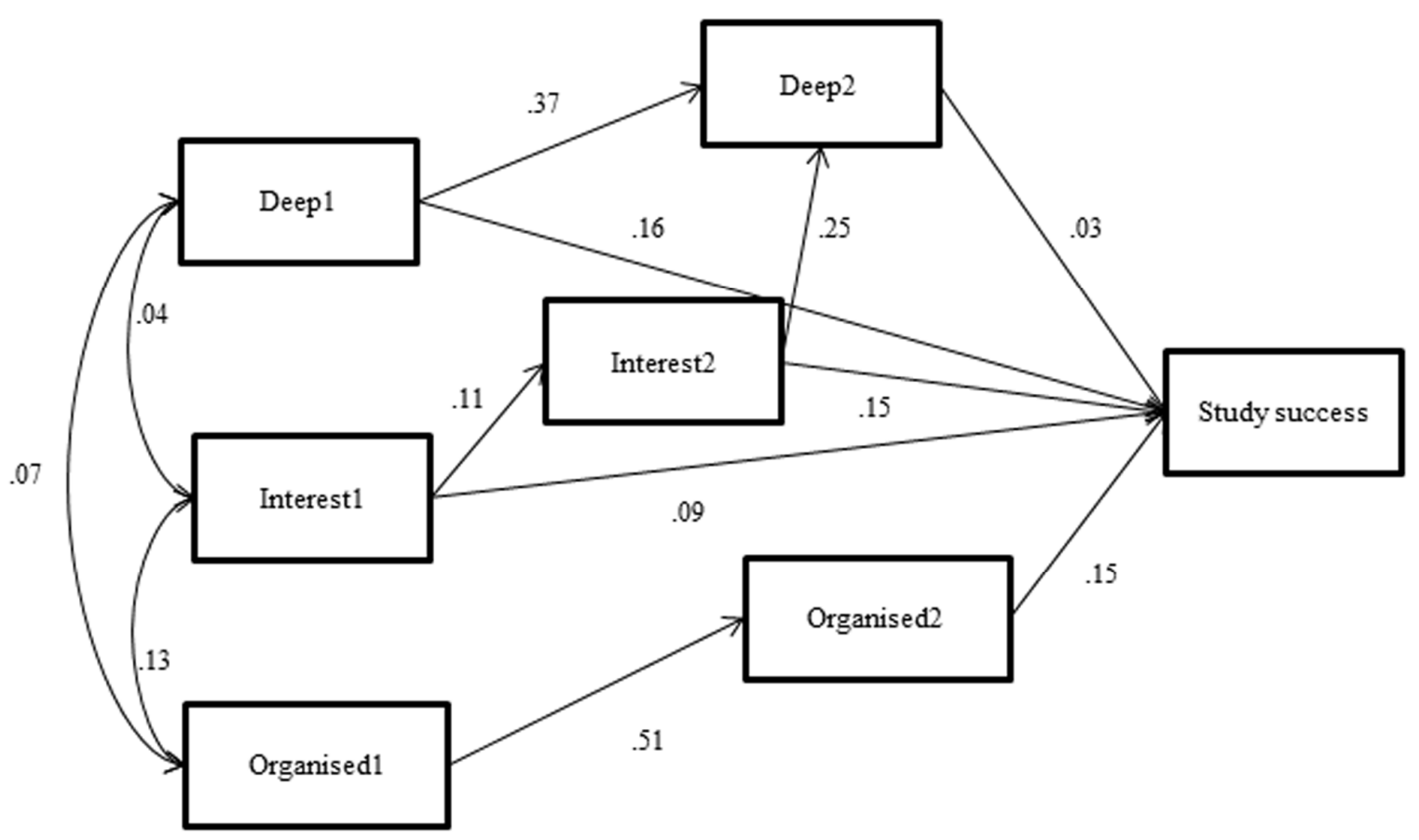

Figure 1. The relationship between approaches to learning, perceptions of the teaching-learning environment and study success in the final year of Bachelor studies.

\section{Discussion}

The aim of this study was to analyse the change in students' approaches to learning and perceptions of the teaching-learning environment from the first to the third year, and how these changes are related to each other in the Faculty of Biological and Environmental Sciences. In addition, the purpose was to see how students' perceptions of the teaching-learning environment and their approaches to learning were related to study success.

We conducted the confirmatory factor analyses based on scales adopted from studies conducted previously with the ETLQ (Entwistle et al., 2003; Parpala et al., 2013). According to the confirmatory factor analyses, only two scales measuring approaches to learning, namely the deep approach and organised studying, were acceptable in the present study. The surface approach and intention to understand scales had only two items and did not fit the model. In addition, four scales measuring students' perceptions of the teaching-learning environment best fit the model. Thus, scales measuring constructive feedback as well as staff enthusiasm and support were excluded from the analyses.

\subsection{Development of Students' Approaches to Learning and Perceptions of Their Teaching-Learning Environment}

According to the present study, students' scores on the deep approach to learning increased from the first to the third year. Thus, students scored higher on looking for evidence to reach conclusions, developing long chains of thought triggered by academic reading, pondering how well students conveyed their point, when communicating ideas, and adopting a different approach if understanding things seemed difficult when studying. These results differ from the results of some earlier studies, which reported a decrease in the deep approach during university studies (Biggs, 1987; Lietz \& Matthews, 2010; Watkins \& Hattie, 1985; Wilding \& Andrews, 2006) or reported no change in the deep approach during tertiary education (Zeegers, 2004). A study by Rodriguez and Cano (2007) found a positive development of the deep approach to learning from the first to the third year of studies, though it was not statistically significant $(\mathrm{p}=0.07)$. The development of the deep approach is a result that is expected and desired during Bachelor studies because one aim of the curriculum in the biosciences is to promote deep-level learning. Bioscience studies are quite general in the beginning of studies; the courses introduce different subjects to students, whereas in the third year, the studies deepen their understanding of their own major subjects. Thus, the deep approach to learning seems to receive greater emphasis during the third year of studies. Furthermore, students' organised studying - more precisely their time management and effort in studying - seems to remain constant. Earlier studies have reported a decline in achieving approach during studies (Lietz \& Matthews, 2010; Wilding \& Andrews, 2006). However, organised studying does not emphasise the motivation to achieve like the 
achieving approach does, but organising and time management skills and effort in studying instead. A positive change in organised studying could have been expected because the nature of the Bachelor studies changes: first year is pre-scheduled, but in the third year, the curriculum offers a lot of optionality, and students must plan their own study schedules.

Students' scores on their perceptions of teaching for understanding decreased during Bachelor studies. In other words, the students felt that in their third year of study the teaching did not encourage them to relate what they learned to issues in the wider world as much as it did in their first year. Furthermore, the results indicate that they felt that their understanding of the subject area was weaker in their third year of studying than in their first year of study. This suggests that students' experience teaching less positively at the end of Bachelor studies. A previous study showed no significant changes in science students' perceptions of their teaching-learning environment during Bachelor studies (Rytkönen \& Parpala, 2010).

Although students' perceptions of the teaching for understanding decreased during Bachelor studies at the group level, changes in the students' deep approach positively correlated with changes in teaching for understanding. More precisely, if students' scores on the deep approach increased during Bachelor studies, their scores on teaching for understanding also increased. This relationship could be expected because earlier studies have found that students' perceptions of teaching are related to the deep approach (Entwistle et al., 2003; Parpala et al., 2010; Rytkönen et al., 2012). These results suggest that some students' scores on the deep approach and perceptions of teaching for understanding decrease. This decrease may be due to the individual nature of students' learning and studying, which indicates that different students follow different study paths. An earlier study has suggested that the ways in which students understand learning in the context of the biosciences can vary greatly (Asikainen, Virtanen, Parpala \& Linblom-Ylänne, 2013b). Future research is needed to explore the individual study profiles more closely. Furthermore, although the changes are related to each other, it is undefinable whether these changes in the perceptions of teaching affect changes in the deep approach or vice versa (Richardson, 2006). Nevertheless, the results of the present study suggest that a change to a more positive perception of teaching is related to a positive change in the deep approach to learning.

\subsection{Predicting Study Success}

The results of the present study show that organised studying is related to study success in the final year of bioscience studies. Namely, if students organise their studies, manage their time well and put effort into their studies, they also receive higher grades in the Faculty of Biological and Environmental Sciences. Organised studying was also related to study success in the first year of bioscience studies (Rytkönen et al., 2012). This suggests that organising and time management skills play an important role in Bachelor studies. In addition, students' interest in the subject and their perceptions of its relevance are related to study success in their final year of Bachelor studies. This suggests that students who find the learning materials interesting enjoy studying and see the relevance of their subject succeed in their studies. This is in line with previous results that suggest that interest and enthusiasm are related to a higher course grade (Ketonen \& Lonka, 2012).

The relationship between the deep approach and study success was not so straightforward. The deep approach in the final year of studies showed no relationship to study success. According to Pearson's correlation, the deep approach in the final year of studies was positively related to study success, but the relationship was not significant $(\mathrm{p}=0.069)$. In the first year of studies, the deep approach also showed no relationship to study success (Rytkönen et al., 2012). However, in the SEM model, the deep approach in the first year predicted study success in the third year. Building a coherent whole from the subject matter and relating ideas already in the first-year instead of just memorising separate facts helps to build a level of understanding which is required in further studies (Biggs, 1999). Lindblom-Ylänne, Lonka and Keskinen (1999) found that higher grades on an entrance examination which measured deep level learning and critical thinking predicted study success at the advanced level of medical studies. These results suggest that a deep approach to learning is important already in the beginning of studies.

One reason for the relationship between study success and the deep approach in the first year could be that in the first year, the standard deviation was greater $(S D=0.73)$, and when the scores for the deep approach increased and the standard deviation decreased $(\mathrm{SD}=0.67)$, the relationship between the deep approach to learning and study success in the third year was no longer significant. In addition, grade point average is only one way of measuring students' study success, and it does not necessarily measure the quality of the learning outcomes (Räisänen, Tuononen, \& Postareff, 2012). For example, it has been found that final exams in biology classes do not necessarily measure students' understanding of the subject matter (Tsaushu et al., 2012). However, the weak relationship between study success and deep approach has been found in other recent studies at university level 
(Diseth, 2007a; Diseth, 2007b; Trigwell, Ashwin, \& Millan, 2013). This raises the question of how vital deep approach to learning is in order to succeed in studies.

The weaker relationship between the deep approach to learning and study success could be due to the fact that deep approach to learning is not necessarily enough to succeed in studies. Previous studies have suggested that students who apply a deep approach to learning but have problems in time management succeed poorly in their studying (Asikainen et al., 2013a; Ruohoniemi, Parpala, Lindblom-Ylänne, \& Katajavuori, 2011). The relationship between study success and organised studying both in the beginning and in the end of Bachelor studies suggest the importance of organising and time management in this context. Parpala et al. (2010) showed that in the Faculty of Biological and Environmental Sciences most common group of students are those who apply a deep approach to learning but do not organise their studies well. The nature of the curriculum changes in the third-year studies so that students need to organise their studying themselves, and the analyses show the importance of organised studying in both first-year and final-year studies. Thus, students who have poor organising skills could have difficulties in succeeding well in their studies.

\subsection{Limitations of the Study}

In the present study, the number of participants was quite small $(\mathrm{N}=103)$. However, with relatively simple models and maximum likelihood estimation, structural equation modelling requires a minimum acceptable sample size of 100 to 150 participants (Hair et al., 2006). Thus, our sample size can be considered as acceptable for the analyses. One problem with small sample size when using structural equation modelling is the limited number of parameters. According to Bentler \& Chou (1987) a ratio of 5 to 1 can be regarded acceptable. In the present study, the final model comprises 23 parameters, and thus, can be regarded as acceptable. In addition, the problem with longitudinal design studies is always the problem of missing values and the loss of participants in the second measurement. According to Richardson (2013), missing values are not random, and students who participate in both measurements tend to differ in their learning and studying from those who do not participate. However, the students who participated in the first measurement did not differ from those who participated in both measurements based on their approaches to learning, their perceptions of their teaching-learning environment or their study success.

Exploring change in students' approaches to learning and their perceptions of their teaching-learning environment can be challenging. With only two measurement points, development or growth is difficult to estimate, and sophisticated methods of analysis, such as multilevel and multi-indicator latent growth analyses, are unusable. However, studies have shown that analyses with more sophisticated analyses are not necessarily always better, and simpler analyses can be efficient enough (Coertjens et al., 2013). The purpose of the present study was to obtain a general picture of the development of Bachelor studies and how students' studying and their perceptions of their teaching-learning environment are related to each other. Thus, the paired sample t-test and regression analyses served to show how the scales changed in their final year of Bachelor studies. In addition, some researchers have questioned the use of change variables in longitudinal studies (Allison, 1990). In the present study, we used change variables on the basis of the regression analyses, as did Gijbels et al. (2008). The purpose was to show the direction of the growth, which cannot be defined solely on the basis of the regression analyses. Furthermore, according to the confirmatory factor analyses, the model with the deep approach and organised studying at the second measurement did not fit as well in the second measurement although the model fit could be considered as acceptable. One reason for this could be that the first year of studies is similar for all students, but in the third year, students specialise into eight different majors and study different courses in the Faculty of Biological and Environmental Sciences. Thus, in the third year, students with different majors study in different contexts from each other.

\subsection{Conclusions}

To summarise, the present study stresses the importance of organised studying in bioscience studies. More precisely students' self-regulation, such as time management and organising skills, and effort in studying seems to be more important in bioscience studies than the deep approach to learning. Thus, time management skills should be supported and emphasised as part of the curriculum and student counselling should aim to help students develop these skills. In addition, the present study suggests that using deep processes, being interested in the subject matter and experiencing it as relevant already in the beginning of their studies leads to better success in studies at the Bachelor level. Furthermore, the present study suggests that the deep approach to learning is changeable, and that this change is related to development of their perceptions of teaching for understanding. Thus, teaching should focus on promoting deep-level learning already in the beginning of the Bachelor degree program. Teaching should encourage students to relate what they have learned to issues in the 
wider world and help them to think about the evidence underpinning different views. Teaching methods which support students' knowledge construction, critical thinking and problem-solving skills, such as problem-based learning, should be integrated into the curriculum from the beginning of their studies to support the development of the deep approach to learning during their Bachelor studies. Furthermore, the results of the present study provide insight to the development of students' approaches to learning and their perceptions of the teaching-learning environment as well as their relationship to study success at the group level. Future research should focus more closely on the relationship between learning, studying and academic achievement at the individual level and explore the validity of course grades as the indicators of the quality of learning outcomes.

\section{References}

Allison, P. (1990). Change scores as dependent variables in regression analysis. Sociological Methodology, 20, 93-114.

Asikainen, H., Parpala, A., Virtanen, V., \& Lindblom-Ylänne, S. (2013a). The relationship between student learning process, study success and the nature of assessment. A qualitative study. Studies in Educational Evaluation, 39(4), 211-217. http://dx.doi.org/ 10.1016/j.stueduc.2013.10.008

Asikainen, H., Virtanen, V., Parpala, A. \& Lindblom-Ylänne, S. (2013b). Understanding students' conceptions of learning in the context of biosciences. International Journal of Educational Research, 62, 36-42. http://dx.doi.org/10.1007/s11251-008-9088-z

Bentler, P. M., \& Chou, C. (1987). Practical issues in structural modeling. Sociological Methods \& Research, 16(1), 78-117. http://dx.doi.org/ 10.1177/0049124187016001004

Biggs, J. B. (1987). Student approaches to learning and studying. Melbourne: Australian Council for Educational Research.

Biggs, J. B. (1999). Teaching for quality learning at university: What the student does. Buckingham: Society for Research into Higher Education: Open University Press.

Biggs, J. B. (2003). Teaching for quality learning at university: What the student does (2nd ed.). Ballmoor, Buckingham: Society for Research into Higher Education, Open University Press.

Coertjens, L., Van-Daal, T., Donche, V., De-Maeyer, S., Vanthournout, G., \& Van-Petegem, P. (2013). Analysing change in learning strategies over time: A comparison of three statistical techniques. Studies in Educational Evaluation, 39(1), 49-55. http://dx.doi.org/ 10.1016/j.stueduc.2012.10.006

Diseth, A. (2003). Personality and approaches to learning as predictors of academic achievement. European Journal of Personality, 17(2), 143-155. http://dx.doi.org/ 10.1002/per.469

Diseth, Å. (2007a). Approaches to learning, course experience and examination grade among undergraduate psychology students: Testing of mediator effects and construct validity. Studies in Higher Education, 32(3), 373-388. http://dx.doi.org/10.1080/03075070701346949

Diseth, A. (2007b). Students' evaluation of teaching, approaches to learning, and academic achievement. Scandinavian Journal of Educational Research, 51(2), 185-204. http://dx.doi.org/10.1080/00313830701191654

Diseth, Å., \& Martinsen, Ø. (2003). Approaches to learning, cognitive style, and motives as predictors of academic achievement. Educational Psychology, 23(2), 195. http://dx.doi.org/10.1080/01443410303225

Dochy, F., Segers, M., \& Buehl, M. M. (1999). The relation between assessment practices and outcomes of studies: The case of research on prior knowledge. Review of Educational Research, 69(2), 145-86. http://dx.doi.org/ 10.3102/00346543069002145

Entwistle, N., \& McCune, V. (2004). The conceptual bases of study strategy inventories. Educational Psychology Review, 16(4), 325-345. http://dx.doi.org/ 10.1007/s10648-004-0003-0

Entwistle, N., McCune, V., \& Hounsell, J. (2003). Investigating ways of enhancing university teaching-learning environments: Measuring students' approaches to studying and perceptions of teaching. In E. De Corte, L. Verschaffel, N. Entwistle, \& J. van Merriënboer (Eds.), Powerful learning environments: Unravelling basic components and dimensions (1st ed., p. 89). Amsterdam: Pergamon.

Entwistle, N., \& Ramsden, P. (1983). Understanding student learning. London: Croom Helm. 
Entwistle, N., \& Tait, H. (1995). Approaches to studying and perceptions of the learning environment. In N. Hativa, \& M. Marincovich (Eds.), Disciplinary differences in teaching and learning: Implications for practice (pp. 93-103). San Francisco: Jossey-Bass Publishers.

Gijbels, D., Segers, M., \& Struyf, E. (2008). Constructivist learning environments and the (im)possibility to change students' perceptions of assessment demands and approaches to learning. Instructional Science, 36(5), 431-443. http://dx.doi.org/ 10.1007/s11251-008-9064-7

Hair, J. F., Black, W. C., Babin, B. J., Anderson, R. E., \& Tatham, R. L. (cop. 2006). Multivariate data analysis (6th. ed.). Upper Saddle River: Prentice Hall.

Ketonen, E., \& Lonka, K. (2012). Do situational academic emotions predict academic outcomes in a lecture course? Procedia-Social and Behavioral Sciences, 69, 1901-1910. http://dx.doi.org/ 10.1016/j.sbspro.2012.12.144

Lietz, P., \& Matthews, B. (2010). The effects of college students' personal values on changes in learning approaches. Research in Higher Education, 51(1), 65-87. http://dx.doi.org/ 10.1007/s11162-009-9147-6

Lindblom-ylänne, S., Lonka, K., \& Leskinen, E. (1999). On the predictive value of entry-level skills for successful studying in medical school. Higher Education, 37(3), 239-258. http://dx.doi.org/ 10.1023/A:1003574125457

Lindblom-Ylänne, S. (1999). Studying in a traditional medical curriculum: Study success, orientations to studying and problems that arise (Doctoral dissertation). University of Helsinki: Helsinki University Press.

Lizzio, A., Wilson, K., \& Simons, R. (2002). University students' perceptions of the learning environment and academic outcomes: Implications for theory and practice. Studies in Higher Education, 27(1), 27. http://dx.doi.org/ 10.1080/03075070120099359

Marton, F., Hounsell, D., \& Entwistle, N. (1984). The experience of learning. Edinburgh: Scottish Academic Press.

Marton, F., \& Säljö, R. (1976). On qualitative differences in learning I - outcome and process. British Journal of Educational Psychology, 46, 4-11. http://dx.doi.org/10.1111/j.2044-8279.1976.tb02980.x

Marton, F., \& Säljö, R. (1984). Approaches to learning. In F. Marton, D. Hounsell, \& N. Entwistle (Eds.), Experience of learning (pp. 39-58). Edinburg: Scottish academic press.

Parpala, A. (2010). Exploring the experiences and conceptions of good teaching in higher education : Development of a questionnaire for assessing students' approaches to learning and experiences of the teaching-learning environment. (Doctoral dissertation). Retrieved from http://urn.fi/URN:ISBN:978-952-10-5955-1.

Parpala, A., Lindblom-Ylänne, S., Komulainen, E., \& Entwistle, N. (2013). Assessing students' experiences of teaching-learning environments and approaches to learning: Validation of a questionnaire used in different countries and varying contexts. Learning Environments Research, 16(2), 201-215. http://dx.doi.org/ 10.1007/s10984-013-9128-8

Parpala, A., Lindblom-Ylänne, S., Komulainen, E., Litmanen, T., \& Hirsto, L. (2010). Students' approaches to learning and their experiences of the teaching-learning environment in different disciplines. British Journal of Educational Psychology, 80(2), 269-282. http://dx.doi.org/10.1348/000709909X476946

Prosser, M., \& Trigwell, K. (1999). Understanding learning and teaching: The experience in higher education. Buckingham: Society for Research into Higher Education.

Räisänen, M., Tuononen, T., \& Postareff, L. (2012). What do course grades tell us about the quality of learning outcomes in biosciences? Paper presented in Sig Higher Education Conference. Tallinn, Estonia.

Richardson, J. T. E. (2005). Students' perceptions of academic quality and approaches to studying in distance education. British Educational Research Journal, 31(1), 7-27. http://dx.doi.org/ 10.1080/0141192052000310001

Richardson, J. T. E. (2006). Investigating the relationship between variations in students' perceptions of their academic environment and variations in study behaviour in distance education. British Journal of Educational Psychology, 76(4), 867-893. http://dx.doi.org/ 10.1348/000709905X69690

Richardson, J. T. E. (2011). Approaches to studying, conceptions of learning and learning styles in higher education. Learning and Individual Differences, 21(3), 288-293. http://dx.doi.org/ 
10.1016/j.lindif.2010.11.015

Richardson, J. T. E. (2013). Research issues in evaluating learning pattern development in higher education. Studies in Educational Evaluation, 39(1), 66-70. http://dx.doi.org/ 10.1016/j.stueduc.2012.11.003

Rodriguez, L., \& Cano, F. (2007). The learning approaches and epistemological beliefs of university students: A cross-sectional and longitudinal study. Studies in Higher Education, 32(5), 647-667. http://dx.doi.org/ 10.1080/03075070701573807

Román, S., Cuestas, P. J., \& Fenollar, P. (2008). An examination of the interrelationships between self-esteem, others' expectations, family support, learning approaches and academic achievement. Studies in Higher Education, 33(2), 127-138. http://dx.doi.org/ 10.1080/03075070801915882

Ruohoniemi, M., Parpala, A., Lindblom-Ylänne, S., \& Katajavuori, N. (2011). Relationships between students' approaches to learning, perceptions of the Teaching-Learning environment, and study success: A case study of third-year veterinary students. Journal of Veterinary Medical Education, 37(3), 282-288. http://dx.doi.org/ 10.3138/jvme.37.3.282

Rytkönen, H., \& Parpala, A. (2010). The change in university students approaches to learning. A lognitudinal study. Paper presented in Earli Sig Higher Education Conference. Kirkkonummi, Finland.

Rytkönen, H., Parpala, A., Lindblom-Ylänne, S., Virtanen, V., \& Postareff, L. (2012). Factors affecting bioscience students' academic achievement. Instructional Science, 40(2), 241-256. http://dx.doi.org/10.1007/s11251-011-9176-3

Trigwell, K., Ashwin, P., \& Millan, E. S. (2013). Evoked prior learning experience and approach to learning as predictors of academic achievement. British Journal of Educational Psychology, 83(3), 363-378. http://dx.doi.org/10.1111/j.2044-8279.2012.02066.x

Tsaushu, M., Tal, T., Sagy, O., Kali, Y., Gepstein, S., \& Zilberstein, D. (2012). Peer learning and support of technology in an undergraduate biology course to enhance deep learning. CBE - Life Sciences Education, 11(4), 402-412. http://dx.doi.org/ 10.1187/cbe.12-04-0042

Watkins, D., \& Hattie, J. (1985). A longitudinal study of the approaches to learning of australian tertiary students. Journal of Practical Research \& Applications, 4(2), 127-15. http://dx.doi.org/ 10.1080/0729436860050207

Wilding, J., \& Andrews, B. (2006). Life goals, approaches to study and performance in an undergraduate cohort. British Journal of Educational Psychology, 76, 171-182. http://dx.doi.org/ 10.1348/000709904X24726

Zeegers, P. (2004). Student learning in higher education: A path analysis of academic achievement in science. Higher Education Research \& Development, 23(1), 35-56. http://dx.doi.org/ $10.1080 / 0729436032000168487$

\section{Copyrights}

Copyright for this article is retained by the author(s), with first publication rights granted to the journal.

This is an open-access article distributed under the terms and conditions of the Creative Commons Attribution license (http://creativecommons.org/licenses/by/3.0/). 